SCJR 13, no. 1 (2018): 1-20

\title{
"To Defend the Citadel of its Faith from All Assaults": Hermann Adler and the London Society for Promoting Christianity Amongst the Jews
}

\author{
ROBERT H. ELLISON \\ ellisonr@marshall.edu \\ Marshall University, Huntington, WV 25755
}

In a sermon preached in London's Bayswater Synagogue on April 25, 1868, the Rev. Dr. Hermann Adler, who would later become Chief Rabbi of the British Empire, ${ }^{1}$ lamented that "immense sums are spent, year after year, by Societies for promoting Christianity among the Jews, in turning bad Jews into worse Christians." ${ }^{2} \mathrm{He}$ was not the only one to express this sentiment. ${ }^{3}$ Well into the twentieth century, the phrase appeared in The Jewish Chronicle, London's leading Jewish newspaper, ${ }^{4}$ and Jews and Gentiles alike alleged that people who came under the influence of such groups too frequently turned out to be "imposters," "false" or insincere converts, and even "profligates" guilty of the "most shameful immoralities."

\footnotetext{
${ }^{1}$ See Geoffrey Alderman, "Adler, Hermann (1839-1911), Chief Rabbi." Oxford Dictionary of National Biography (henceforth ODNB) (September 23, 2004), on line, retrieved October 20, 2018.

${ }^{2}$ Hermann Adler, A Course of Sermons on the Biblical Passages Adduced by Christian Theologians in Support of the Dogmas of Their Faith (London: Trübner \& Co, 1869), 2.

${ }^{3}$ The Jewish Chronicle published a great many similar pieces. Some were the newspapers' own articles; others were letters to the editor; and still others were excerpts of articles from publications like The Edinburgh News, The Morning Chronicle, and The Pall Mall Gazette. The number of these publications suggests the extent of the criticisms leveled at such societies from virtually their earliest days. An entire periodical, The Faithful Missionary, started in 1847, "had for its object to expose the fraudulent methods of the London Society for Promoting Christianity among the Jews" (Isidore Harris, "The Anglo-Jewish Press. Its Story Briefly Told," The Jewish Chronicle [November 24, 1916]: 24).

${ }^{4}$ Some of these articles directly cited Adler as the source of the phrase. See, for example, "Week by Week" (January 8, 1909: 9), and pieces by "Mentor" published on October 29, 1909 ("In the Communal Armchair," 7) and November 16, 1928 ("Codlin's the Friend," 9). Other uses that did not acknowledge Adler appeared as early as December 11, 1891 ("Notes of the Week," 6) and as late as August 26, 1921 (I. Livingstone, "Conversionist Activity. A Plea for Action," II).

${ }^{5}$ Henry Handley Norris, The Origin, ... of the London Society for Promoting Christianity Amongst the Jews...(London: J Mawman, 1825), 56; Zailick Solomon, An Exposure of Hypocrisy and Bigotry and a Strenuous Vindication of the Israelites: In an Address to the Members of a Society Formed for Promoting Christianity Amongst the Jews, ... (London: E Justins, 1822), 13; "On the London Society for Converting the Jews," The British Critic 11 (1819): 26, 30; "Missions to the Jews," Westminster
} 
Adler might have had any number of "Societies" in mind. According to an Encyclopaedia of Missions published in 1891, at least fifteen organizations for "conversionists" were active in Victorian Britain. The list includes The British Society for the Propagation of the Gospel among the Jews, The Jewish Mission of the Presbyterian Church of England, the Barbican Mission to the Jews, the Jewish Mission of the Church of Scotland, and the Ladies' Association for the Christian Education of Jewish Females. ${ }^{7}$ Adler's phrasing, however, appears to single out the most prominent of these, the London Society for Promoting Christianity Amongst the Jews. Founded early in the nineteenth century, it still exists today as the Church's Ministry among Jewish People. This group, hereafter referred to simply as "the Society," is the subject of this article. ${ }^{8}$

The Society had its roots in the London Missionary Society under the leadership of Joseph Samuel Christian Frederick Frey, a Jewish convert to Christianity who became a prominent and controversial figure in missionary work on both sides of the Atlantic. ${ }^{9}$ In 1808, a separate organization was launched, "The London Society for the Purpose of Visiting and Relieving the Sick and Distressed,

Review 125, no. 249 (1868): 170; Tobias Goodman, An Address to the Committee of the London Society for Promoting Christianity among the Jews, ... (London: W. Day, 1809), 27.

${ }^{6}$ The Jewish Chronicle often used this term. See "A.W."'s response in one of the Society's in-house publications, "The Jewish Chronicle and the Conversionists," Jewish Intelligence... (October 1, 1863): 246-9.

7 "Jews," in The Encyclopaedia of Missions..., vol. 1, ed. Edwin Munsell Bliss (New York: Funk \& Wagnalls, 1891), 509-11.

${ }^{8}$ Studies of English Judaism frequently mention the Society, but it is the primary focus of relatively few works. The only book-length treatments were written by officers of the Society and thus take a rather sympathetic view. See, for example, Thomas D. Halsted, Our Missions: Being a History of the Principal Missionary Transactions of the London Society... (London: William Macintosh, 1866) and W. T. Gidney, The History of the London Society for Promoting Christianity... (London: London Society for Promoting Christianity Amongst the Jews, 1908). Later articles, however, are somewhat more critical. R. H. Martin, for example, has asserted that while the Society may have "performed a very important function for poor Jewish immigrants as an early welfare agency," internal divisions over doctrine and missionary strategies led to its "failure" as an "interdenominational" or "panevangelical" group ("United Conversionist Activities among the Jews in Great Britain 1795-1815: Pan-Evangelicalism and the London Society for Promoting Christianity Amongst the Jews," Church History 46, no. 4 [1977]: 438, 51, 52). Robert Michael Smith goes even further, arguing that Victorian-era attempts to convert the Jews "failed miserably" and noting the irony that "the Sephardim, almost completely ignored by The Society, converted to Christianity in large numbers, while the Ashkenazim, among whom The Society concentrated its weapons, had so few converts as to make The Society's efforts meaningless" ("The London Jews' Society and Patterns of Jewish Conversion in England, 1801-1859," Jewish Social Studies 43, no. 3/4 [1981]: 275).

${ }^{9}$ Joseph Samuel Levy (b. Germany 1771) took the name Christian Frederick Frey upon his baptism into the Lutheran Church in 1798. He arrived in England in 1801. A sexual-misconduct scandal in 1816 caused him to leave England for America, where he resumed his missionary work with such organizations as the American Society for Meliorating the Condition of the Jews (ASMCJ). See his autobiographies: The Converted Jew: Or Memoirs of the Life of Joseph Samuel C.F. Frey... (Boston: Samuel T. Armstrong, 1815); Narrative of the Rev. Joseph Samuel C.F. Frey... (New York: W B Gilley, 1817); and Judah and Israel... (New York: D. Fanshaw, 1841), 1-145. See also George L. Berlin, "Joseph S. C. Frey, the Jews and Early Nineteenth Century Millenarianism," Journal of the Early Republic 1, no. 1 (1981): 27-49; David Max Eichhorn, Evangelizing the American Jew (Middle Village, N.Y.: Jonathan David, 1978), 18-26; Lee Max Friedman, Early American Jews (Cambridge, Mass: Harvard University Press, 1934), 96-112. 
and Instructing the Ignorant, Especially Such as are of the Jewish Nation." Its mission soon proved to be as unwieldy as its name, and, after some reorganization, it was launched anew the following year as "The London Society for the Promotion of Christianity Amongst the Jews." This was slightly revised to "The London Society for Promoting Christianity Amongst the Jews," the name it held for the rest of the nineteenth century. Its denominational affiliations changed as well: at first, both Anglicans and Dissenters contributed to the work, but following disputes over financial management and other issues, the Dissenters withdrew in 1815; from that point forward, in the words of a report published that year, the Society would be "Conducted on the Principles of the Established Church."

Scholars have studied many aspects of the work of the Society, but not its sermons, the focus of this article. This is despite the fact that in recent decades, sermon studies has come into its own. ${ }^{11}$ However, even in the renaissance of that field, almost no attention has been given to interfaith preaching, a source that sheds significant light on Jewish-Christian relations. As a point of entry into that conversation, this article will address three dimensions of the topic: sermons delivered by preachers speaking on the Society's behalf; those delivered by Adler in an effort to keep the Jewish community from succumbing to the conversionists' influence; and pamphlets and books that, in turn, sought to challenge Adler's views and offer additional arguments in support of Christian views.

\section{The Society's Sermons to Christian Audiences}

The Society's sermons to Christian audiences largely followed the prevailing conventions of the day in style and content. An introduction to the scripture text on which the discourse was based was followed by an exposition or explanation of that text, often divided into several main points, or "heads." Their concluding application suggested changes in belief or behavior that should take place in light of what the congregation had learned. Little marked the sermons as specifically Baptist, Congregationalist, or Anglican. Their common goal was speaking on behalf of the Society and they are all best described as "broadly evangelical."." Of interest here are matters of rhetoric rather than doctrine or theology; this article

\footnotetext{
${ }^{10}$ Gidney, History of the London Society, 52. See also Halsted, Our Missions, 18-21; Martin, "United Conversionist Activities," 444-50; Smith, "London Jews' Society," 275-78. Halsted's appendix listing preachers reflects this change.

${ }^{11}$ See Robert H. Ellison, "Some Reflections on the Field of Sermon Studies," The Journal of Religious History, Literature and Culture 1, no. 1 (2015): 32-41. Recent major studies of Christian and Jewish preaching include The Oxford Handbook of the Early Modern Sermon, ed. Peter E. McCullough, Hugh Adlington, and Emma Rhatigan (Oxford: Oxford University Press, 2011); The Oxford Handbook of the British Sermon 1689-1901, ed. Keith A. Francis and William Gibson (Oxford: Oxford University Press, 2012); and Marc Saperstein, Agony in the Pulpit: Jewish Preaching in Response to Nazi Persecution and Mass Murder: 1933-1945 (Cincinnati, OH: Hebrew Union College Press, 2018).

${ }^{12}$ For a discussion of Victorian homiletic theory, see Robert H. Ellison, The Victorian Pulpit: Spoken and Written Sermons in Nineteenth-Century Britain (Selinsgrove: Susquehanna University Press, 1998), 18-32; "The Tractarians' Sermons and Other Speeches," in A New History of the Sermon: The Nineteenth Century, ed. Robert H. Ellison (Leiden; Boston: Brill, 2010), 15-57.
} 
will examine how the preachers crafted their messages for various audiences to increase our understanding of how the Society attempted to achieve its goal of "promoting Christianity amongst the Jews."

Preachers representing the Society delivered sermons to Christians on a range of occasions. Its "flagship" discourses were the "anniversary sermons," delivered during the annual meetings that took place each May. ${ }^{13}$ There were no set topics or other required parameters; the 1817 "Rules and Regulations" simply stated that "Two Anniversary Sermons shall be preached at such times and at such places of worship, connected with the Church of England, as the Committee may think proper." Testament missions-related verses. Romans was by far the most popular source, with significant numbers of sermons drawn from Isaiah and Luke as well.

These passages are a mix of the more and less predictable. As we might expect, most of the sermons on Luke come from chapter 2, where we read proclamations from the angels and Simeon that the infant Jesus is "a Savior," a "light for revelation to the Gentiles, and for glory to your people Israel" (Luke $2: 11,32$ ). Similarly, the discourses on Romans focus largely on chapters 10 and 11, where Paul expresses his "heart's desire...that [the Jews] may be saved" and prophesies that "all Israel" will in fact "be saved" after "the fullness of the Gentiles has come in" (Romans 10:1; 11:25-26). The sermons on Isaiah, however, do not address well known passages such as 7:14-"Behold, a virgin shall conceive, and bear a son, and shall call his name Immanuel"-and 53:5-"But he was wounded for our transgressions... and with his stripes we are healed." Instead, verses discussed in the anniversary sermons include 40:1-2 - "Comfort ye, comfort ye my people..." - and 64:1-4 - “...men have not heard...what [God] hath prepared for him that waiteth for him."

Whatever the text under consideration might have been, a notable feature of these sermons is the extent to which they present the Society as the fulfillment of God's prophetic plan. In his 1819 anniversary sermon, the Staffordshire rector Edward Cooper stated that "the Conversion of the Jews to Christianity," as envisioned by Paul in Romans 11 and elsewhere, was "the avowed, and exclusive Object pursued by the Society." 15 Thomas Tattershall, a priest from Liverpool, said much the same thing in 1839, stating that God wants to restore his "blessings" to the Jews and that the Society exists "for the express purpose of furthering...this part of the will of the Most High."16

Several who preached in the intervening years suggested that the Society was succeeding in its purpose. In 1814, Henry Ryder, Dean of Well's Cathedral in

\footnotetext{
${ }^{13}$ Halsted, Our Missions, Appendix B, 11-13 lists the anniversary sermons and preachers from 18091858.

${ }^{14}$ The Ninth Report of the Committee of the London Society for Promoting Christianity Amongst the Jews, Read at the General Meeting, May 9, 1817 (London: A Macintosh, 1817), viii.

15 "Eleventh Anniversary Sermon by the Rev. E. Cooper," in The Eleventh Report of The London Society For Promoting Christianity Amongst The Jews... (London: A. Macintosh, 1819), 7.

${ }^{16}$ Thomas Tattershall, A Sermon Preached at the Episcopal Jews' Chapel... (London: A. Macintosh, 1839), 7.
} 
Somerset, ${ }^{17}$ preached an anniversary sermon applying Luke 24:34, "Father, forgive them; for they know not what they do," to the Jews as well as to the Roman soldiers, stating that "They were the men who forced Pilate...against his will to consent to the execution" and that they took upon themselves "an exclusive share in the deed" when they declared "His blood be on us, and on our children." He goes on to say that Jesus is still interceding for "the modern Jew," but he "cannot be reached without a distinct establishment expressly appropriated and suited to his case." The Society, naturally, is just such an organization, and it is "under [its] auspices" that the Jews will find employment, have access to "useful and religious education," and-most importantly_-"be converted and brought to a saving knowledge of the truth." 18

In their sermons on Isaiah, George Stanley Faber and Thomas T. Thomason took much the same approach. In 1822, Faber, rector of Long Newton in County Durham, ${ }^{19}$ preached an anniversary sermon on Isaiah 60:1-5. In Faber's view, the conclusion of this passage — " "thine heart shall fear, and be enlarged; because the abundance of the sea shall be converted unto thee, the forces of the Gentiles shall come unto thee"-refers to events that will take place very close to the end of the age: the Jews will be converted to Christianity en masse, and will bring "the great unreclaimed mass of the Gentiles...into the Church" with them. A logical question to ask, then, is when will this time come? Faber acknowledges that while "no man can be absolutely certain as to the exact year," we can "safely pronounce the conversion and restoration of the Jews to be near at hand." This can be seen, he suggests, in increased missionary work among the Christians and a corresponding "intense curiosity" about spiritual matters among the Jews. Faber gives the Society a good deal of credit for these developments, asserting that the "very existence" of an organization "whose special object is to evangelize the house of Judah in every quarter of the globe" is one sign that "that the hand of God is now specially stretched forth upon the earth."20

Thomason, chaplain of the East India Company and the anniversary preacher for 1828, made his focus on the Society explicit from the start, stating that the organization "whose object we are now assembled to promote...completes the circle of missionary exertions, which so honourably distinguishes the present age." He offers even higher praise a few pages later, asserting that if one were to compare "the present state of the Christian world, with what it was before the formation of this Society...we have abundant cause to thank God and take courage" that their labors would continue to bear fruit. Those efforts will succeed, he says, because "they are paving the way for the accomplishment of prophecy." His

\footnotetext{
${ }^{17}$ See Mark Smith, "Ryder, Henry (1777-1836), Bishop of Lichfield and Coventry." ODNB (September 23, 2004), on line, retrieved September 9, 2018.

${ }^{18}$ Henry Ryder, A Sermon Preached at the Parish Church of St. Bride's... (London: B. R. Goakman, n.d.), 4, 9-10, 11, 22.

${ }^{19}$ See G. C. Boase, "Faber, George Stanley (1773-1854), Church of England Clergyman and Religious Writer.” ODNB (September 23, 2004), on line, retrieved September 9, 2018.

${ }^{20}$ George Stanley Faber, The Conversion of the Jews to the Faith of Christ... (London: Hatchard, Ogle, Duncan, \& Co, 1822), 26, 31, 47, 49.
} 
text for the sermon, Isaiah 30:18, includes the prophecy, “ $\ldots$ blessed are all they that wait for him." This "they," he says, refers not only-and perhaps not even primarily - to the people of Israel, but rather to Christians, and specifically to the members of the Society, who are, he says, "workers together with God." Consequently, their work is bound to thrive; Faber and Thomason respectively end their sermons with the promises that "God, even our own God, shall give us his blessing" and that "in God's own good time, your labour shall not be in vain." 21

One of the lengthiest discussions of the Society's work appears in the 1847 anniversary sermon preached by William Dalton, a priest in the West Midlands town of Wolverhampton. Dalton explicitly divides his discourse into "a brief exposition of my text," to be followed by the "actual appeal in behalf of [the] Society." The exposition is not noticeably different than those found in other anniversary sermons in its interpreting its text, here Daniel 12:1-3, to motivate the assembled to strive for "the conversion of the Jewish people to the saving knowledge of the great and gracious Messiah." 22

Dalton's appeal, however, is unusual, perhaps even unique. Like Faber and Thomason, he commends the Society's missionaries for being "pre-eminently faithful in the declaration of the grace of God," but he does not stop there. He goes on to discuss the Society's income, educational endeavors, numbers of missionaries and converts, and the presence it has established overseas, especially "in the city of David." ${ }^{23}$ This information is generally provided in the Society's annual reports; by including it here as well, Dalton may, strictly speaking, be going beyond the parameters of a sermon, which traditionally focuses on the exposition and application of a scripture text. It may not, however, be an entirely inappropriate approach, as it gives supporters an additional means of being informed about the details of the Society's work.

\section{The Society's Sermons to Jewish Audiences}

Jewish and Christian clergy in the nineteenth century addressed members of other faiths in various contexts, including friendly pulpit exchanges. ${ }^{24}$ The Society, though, wanted Jews to come to them. One history noted that "Courses of sermons to the Jews" were preached in "the Episcopal Chapel, Ely Place, and other Church of England places of worship in London, and also at Bristol, Chatham and Sheerness. ${ }^{25}$

Two venues were devoted exclusively to the Society's outreach to the Jews. The Jews' Chapel was established in 1809, in the Spitalfields area of London.

\footnotetext{
${ }^{21}$ Thomas T. Thomason, Sermon Preached at the Parish Church of St. Paul, Covent Garden... (n.p., n.d.), 3, 5, 10, 23; Faber, The Conversion of the Jews, 52.

${ }^{22}$ William Dalton, A Sermon: Preached at the Parish Church of the United Parishes of Christ Church, Newgate Street... (London: B. Wertheim, 1847), 6, 26.

${ }^{23}$ Dalton, A Sermon, 29-35.

${ }^{24}$ Mirela Saim, "The Modern Renewal of Jewish Homiletics and the Occurrence of Interfaith Preaching," in A New History of the Sermon: The Nineteenth Century, ed. Robert H. Ellison (Leiden; Boston: Brill, 2010), 457-88.

${ }^{25}$ Gidney, History of the London Society, 39.
} 
Each week, three different kinds of addresses were delivered there to Jewish audiences: "a sermon...every Sunday evening...a lecture on the Epistle to the Hebrews every Wednesday evening, and an Exhortation on Friday. ${ }^{26}$ Once a quarter, there would also be "Demonstration Lectures," discourses intended to prove the "Lord Jesus Christ to be the true Messiah." 27 The lectures were also published with the hope that they would be "extensively distributed among the Jews" and become "a powerful instrument in the Hands of God for extending the Redeemer's kingdom.",28

In July 1814, the Society opened the Episcopal Jews' Chapel in Bethnal Green to complement the Jews' Chapel. While the target audience in Spitalfields was Jews who had not yet made the decision to convert, the chapel in Bethnal Green offered Christian worship. In an anniversary sermon delivered in May 1813, shortly after the Duke of Kent laid the Chapel's foundation stone, Francis Randolph $^{29}$ set forth his - and presumably the Society's — vision for the Chapel:

I see a building erected unto holiness; a temple dedicated unto Jehovah, in whose ritual, duties, and ordinances, the offering of Judah and Jerusalem shall be pleasant unto the Lord; and wherein, hailing their true Messiah...the Jews shall follow the Christians in transports of joy, and cry out, Hosannah to the Son of David... and where, both shall elevate their praises in one harmonious tone of rapturous gratitude, and sing, Salvation to our God. ${ }^{30}$

The sermons at Bethnal Green continued for many years: sermons to the Jews were preached at least into the late 1830s; the last anniversary sermon delivered there took place in $1860 .{ }^{31}$ The discourses at Spitalfields, however, were somewhat short-lived, discontinued due to issues concerning ecclesiastical governance. Frey, one of the early preachers there, proved either unable or unwilling to seek Anglican ordination, and his association with it ended in $1816 .^{32}$ Parish officials were also apparently unwilling to "license" the building itself, and in 1816 or 1817 , steps were taken to "dispose of it" altogether. ${ }^{33}$

There is not a great deal of evidence concerning how many Jews were present at these services, or why they chose to attend. The Society's first two reports gave estimates of 50-100 and 200-500 people; after that, no numbers appear at

\footnotetext{
${ }^{26}$ Halsted, Our Missions, 33.

${ }^{27}$ Gidney, History of the London Society, 39.

28 "Origin of the London Society," The Jewish Repository, or Monthly Communications Respecting the Jews, and the Proceedings of the London Society 1 (1813): 149.

${ }^{29}$ See G. Le G. Norgate, "Randolph, Francis (1752-1831), Church of England Clergyman." ODNB (September 23, 2004), on line, retrieved September 9, 2018.

${ }^{30}$ Francis Randolph, A Sermon Preached at St. Clement Danes, Strand... (London: B. R. Goakman, 1813), 28-29.

${ }^{31}$ Edward Bickersteth, The Way of Christ Prepared... Second Edition, (London: J. Duncan, 1838); Gidney, History of the London Society, 327.

${ }^{32}$ Gidney, History of the London Society, 57; Frey, Narrative, 168-69.

${ }^{33}$ Ninth Report, 21-22.
} 
all, replaced by "well attended," "a considerable number," "a respectable congregation," and other less than precise words. ${ }^{34}$

The statements preserved concerning motive come from the Society and its critics, not from the attendees themselves, and thus may need to be viewed with caution. The Society, for example, asserted that the lectures and sermons stirred spiritual "interest" and "inquiry" in the Jews, suggesting that such interest was also what first drew them to attend. ${ }^{35}$ Many critics, on the other hand, maintained that the Society appealed to Jewish self-interest rather than their souls. Bribery is often listed among the unjust practices the Society allegedly employed to achieve various goals, ${ }^{36}$ including increased attendance at chapel services. ${ }^{37}$

Both, of course, may be true. Whatever the exact numbers and motivations, sermons were preached with Jews present. Most of the sermons were either never published or have been lost; the ones we do have allow us to infer how Society preachers addressed both converted and unconverted Jews.

The ways in which the preachers speak both to and about their Jewish audiences are key features of these texts. Andrew Fuller ${ }^{38}$ began his November 19, 1809 Spitalfields sermon by acknowledging that he had "some peculiar feelings on account of the audience, part of which, I am given to understand are of the house of Israel." He speaks kindly about the Jews at the beginning of the sermon, noting the spiritual "debt we owe to that distinguished people"; addresses them directly throughout; and makes an earnest appeal to them at the end, declaring "O! ye children of Israel, our hearts [sic] desire and prayer to God for you, is, that you may be saved." 39

The following year, also at Spitalfields, John Ryland ${ }^{40}$ likewise acknowledged that he was preaching to "both you that believe in Jesus, and you of the seed of Abraham"; two-thirds of the way through the sermon, he states, "let me earnestly entreat the candid attention of the descendants of Abraham." He sometimes speaks in the third person, with phrases such as "I request the Jews also to consider," but these statements are outweighed by direct address. He declares that "all true Christians long for your salvation" and says "I urge you to enquire, how can you hope for the pardon of sin, who do not look for a suffering Messiah, to

\footnotetext{
${ }^{34}$ Extracts from the Society's annual reports are given in Frey, Narrative, 158, 59, 60, 73, 204.

${ }^{35}$ Frey, Narrative, 165; Halsted, Our Missions, 35.

36 “A Daughter of Israel," Letter to Mr. Frey of the Soi-Disant Jews'-Chapel, Spitalfields... (London: L. Alexander, 1810), 4; "The Liverpool Meeting of Conversionists," The Jewish Chronicle and Hebrew Observer (December 30, 1864): 4; Norris, The Origin,... of the London Society, 451; Solomon, An Exposure of Hypocrisy and Bigotry, 27; "The Conversionists Again," The Voice of Jacob (March 17, 1843): 131; "Doings of the Conversionists," The Voice of Jacob (August 18, 1843): 219; S. Hoga, "The Faithful Missionary," The Jewish Chronicle (August 20, 1847): 228.

${ }^{37}$ Harvey W. Meirovich, "Ashkenazic Reactions to the Conversionists, 1800-1850," Transactions \& Miscellanies (Jewish Historical Society of England) 26 (1974): 7; "A Peep into the Missionary Efforts," The Jewish Chronicle (October 27, 1854): 86.

${ }^{38}$ See E. F. Clipsham, "Fuller, Andrew (1754-1815), Baptist Minister and Theologian." ODNB (September 23, 2004), on line, retrieved October 20, 2018.

${ }^{39}$ Andrew Fuller, Jesus the True Messiah... (London: Black, Parry, and Kingsbury, 1810), 3, 31.

${ }^{40}$ See E. F. Clipsham, "Ryland, John (1753-1825), Baptist Minister and Theologian." ODNB (September 23, 2004), on line, retrieved October 20, 2018.
} 
make real and lasting atonement?" He concludes with a mention of both groups, anticipating the day that "Millions of redeemed Jews, millions of saved Gentiles, shall then unite in the everlasting song, "Worthy is the Lamb that was slain...",41

Similarly, in an 1837 sermon preached in the Episcopal Jews' Chapel, Edward Bickersteth ${ }^{42}$ said that he wanted to address the Jews in his audience with the same "plainness" and "spirit of love" with which he spoke to Christians. He warns them of the danger of such sins as "self-righteousness," "covetousness," observing the "traditions of men," and especially "unbelief in the Son of God." In each case, he discusses the sin from the perspective of the Hebrew Scriptures, and appeals to them to set aside the "stumbling-blocks" that are keeping them away from God. He ends by focusing not on the consequences of leaving the blocks in place, but rather on the "blessed fruits of their removal." Once they are gone, he says, they will be replaced by "revival and healing," "comfort and peace," and "gladness and glory." His final appeal is that both "Jews and Christians" will "shine forth over all the earth."

Thomas Raffles ${ }^{44}$ took a rather different tone. The published version of The Claims of Jesus of Nazareth Examined, a sermon he preached in the Spitalfields chapel on August 19, 1810, contains something of a disclaimer or "content advisory." "If any Jew," he wrote:

casting his eye over this Sermon, should deem some of the expressions contained in it too severe, the author entreats that he will not regard language (which, however true, had he written under less powerful impressions, might have been more mild) as at all affecting the general argument; but only dwell upon that which, in the estimation of every candid reader, would be regarded as cool and dispassionate reasoning.

Raffles had good reason to be concerned. He had no way of knowing, of course, whether Jews would read his printed text, but he was well aware that "children of Israel" were in the Spitalfields chapel that day. His tone is the antithesis of Fuller's and Bickersteth's. When he speaks to the Christians in the audience about the Jews, he speaks of their "deplorable state of degradation and guilt." When he addresses Jews directly, he says they are "miserable and degraded"; accuses them of "licentiousness," pride," "prejudice" and "malignity"; and states that anyone who "refuses to believe, forfeits his rank in the creation of God, and is no longer worthy the name of a rational and intelligent being." Most of his exposition of Luke 7:19, in which John the Baptist's disciples ask "Art thou he that should come, or look we for another?," is deliberate, methodical, and logical, but

\footnotetext{
${ }^{41}$ John Ryland, Eight Characteristics of the Messiah... (London: B. R. Goakman, n.d.), 4, 20, 21, 23, 25,30 .

${ }^{42}$ See John Wolffe, "Bickersteth, Edward (1786-1850), Church of England Clergyman and Evangelical Leader." ODNB (September 23, 2004), on line, retrieved October 20, 2018.

${ }^{43}$ Bickersteth, The Way of Christ Prepared, 9, 10, 12, 13, 14, 15, 16.

${ }^{44}$ See Alexander Gordon, "Raffles, Thomas (1788-1863), Congregational Minister." ODNB (September 23, 2004), on line, retrieved October 20, 2018.
} 
language such as this is anything but "cool and dispassionate." It would most likely have worked against his purpose, calling into question his earnestness and compassion for the Jews and actually reducing the likelihood that they would respond to his appeal to "turn and seek the Lord your God." ${ }^{45}$ We have no evidence for language of this sort in Ryland, Fuller and Bickersteth's preaching in the same context.

\section{Adler's Course of Sermons}

Adler's attitude toward the Society and its sermons was consistent with some of his contemporaries. In mid-century, David Woolf Marks ${ }^{46}$ responded to conversionary pressures in sermons entitled "Conduct Without Principle" (October 31, 1846) and "On the Doctrine of the Advent of Messiah" (May 1, 1858). He was not in favor, he wrote, of using the pulpit to "attack the religion of a brother man," or of raising issues that were likely to "encounter considerable prejudice and opposition." If, however, "genuine principles of religion are concerned...nothing ought to restrain us from adopting and defending them." When Jewish preachers challenge or refute the "conversionists" from the pulpit, they are not "indulging the remotest idea of propagandism"; rather, they are "discharging [their] imperative duty" to uphold the doctrines that have been "revealed by God" and warn their people against embracing those that have been "merely...inferred by mortal man." 47

Simeon Singer ${ }^{48}$ expressed a similar view in a 1901 sermon delivered in the New West End Synagogue. He notes that "tolerance is a vital part of the Jewish character and teaching," probably as a result of the "centuries of oppression and persecution" that the Jews had had to endure. Consequently, he asserts that there is seldom any "moral victory" to be gained by "crushing" people, or "by forcing them to any outward or verbal acceptance of your views, however precious they may be to you." ${ }^{49}$ This echoes the 1885 words of the Rev. J. Polack of the Prince's Road Synagogue in Liverpool, who made an important distinction between the messenger and the message:

While it is imperative that no harsh thought should dwell in our minds and no offensive word escape our lips in regard to persons, I deem it absolutely es-

\footnotetext{
${ }^{45}$ Thomas Raffles, The Claims of Jesus of Nazareth Examined... (London: B. R. Goakman, 1811), 4, $8,12,28,31,32$.

${ }^{46}$ See M. Epstein, "Marks, David Woolf (1811-1909), Rabbi and Hebrew Scholar." ODNB (September 23, 2004), on line, retrieved October 20, 2018.

${ }^{47}$ David Woolf Marks, Sermons Preached on Various Occasions, at the West London Synagogue of British Jews (London: R. Groombridge and Sons, 1851), 59; Marks, Sermons Preached on Various Occasions at the West London Synagogue of British Jews, (London: Trübner, 1885), 67-68.

${ }^{48}$ See "Singer, Simeon (1848-1906), Rabbi." ODNB (September 23, 2004), on line, retrieved October 20, 2018.

${ }^{49}$ Simeon Singer, The Literary Remains of the Rev. Simeon Singer: Sermons (London: G. Routledge, 1908), 236, 239.
} 
sential...that principles which we reject should be frankly considered, and their inconclusive and irrational character, if necessary, clearly established. ${ }^{50}$

Adler strikes much the same tone in A Course of Sermons. He begins the first address by reminding his audience that "Judaism is not a proselytizing faith," that it "seeks neither to make converts nor to attack other creeds, believing as it does that 'the sincere and virtuous professors of every religion may hope to enjoy future bliss'." He does, however, reserve the right to respond when threatened or attacked, to "defend the citadel of its faith from all assaults" and to not "allow one single member of [his] flock to stray from the fold."

Adler's defensive strategy, as outlined in his fourth sermon, can be summed up in two words: text and context. To determine the proper meaning of a "disputed" verse, interpreters must set aside "the Anglican version," whose authors, he says, "were swayed by dogmatic preconceptions." They should instead use "a translation, composed by a scholar, thoroughly versed in the Hebrew tongue," or - even better - consult "the original" language. They must also look past "the passage as it stands by itself" and consider the surrounding material as well. In so doing, they "will find, that all the superstructure which had been erected upon it... will shake from its foundation, and crumble into dust." $" 52$

In the same sermon, Adler acknowledges that he cannot "consider all the passages of Scripture which are brought forward by Christian theologians in support of their dogmas." ${ }^{53}$ His discussions are nonetheless wide-ranging: Numbers, Deuteronomy, Hosea, Micah, Zechariah, and Ecclesiastes all receive at least some mention, with Isaiah and Daniel gaining perhaps the most attention.

He begins with Isaiah 7:14, "Behold, a virgin shall conceive and bear a son." "Virgin," he asserts, is a mistranslation; the Hebrew word almah "simply denotes a young woman, one who is either marriageable or already married." The context is significant as well, as Isaiah's mission in this passage is to reassure Ahaz, king of Judah, that the attacks being waged on him by the kings of Syria and Israel would not succeed. Properly interpreted, then, the word translated "virgin" is not a prophecy of Mary, but rather a reference to "the young wife of the prophet himself." In Adler's view, it was she who would "bear a son, whom she was to call Immanuel, this name being intended to indicate the protection which the Lord would grant the nation." 54

He then applies his two-part exegesis to Isaiah 9:6-7-"For unto us a child is born..."- and Isaiah 52-53's "suffering servant" passages. He asserts that Christian interpretations of these texts are based on mistranslations: "mighty God," for

\footnotetext{
${ }^{50}$ J. Polack, "The Unity of God," The Jewish Pulpit 9 (1885): 104.

${ }^{51}$ Adler, Course of Sermons, 1. Compare his June 29, 1895 sermon, "Jew and Gentile," and his June 23, 1891, "The Ideal Jewish Pastor," preached at his installation as Chief Rabbi (in Anglo-Jewish Memories and Other Sermons [London: George Routledge and Sons, 1909], 80-94, 279-88). He does not allude to the Society or other Christian missionaries, but acting as a "defender of the faith" would be one of the defining characteristics of his tenure as Chief Rabbi.

${ }^{52}$ Adler, Course of Sermons, 49.

${ }^{53}$ Adler, Course of Sermons, 48.

${ }^{54}$ Adler, Course of Sermons, 16-19.
} 
example, should instead be rendered "mighty hero"-a human reference, not a divine one - and that the pronoun in 53:8 is plural rather than singular, reading "for the transgression of my people were they stricken," so the verse cannot be taken as a prophecy of Christ. ${ }^{55}$

A study of the context will then reveal the proper identity of the hero and the people who were stricken. The verses before and after Isaiah 9:6 "speak distinctly of the campaign which the King of Assyria, Sennacherib, is about to undertake against Jerusalem." "Deliverance" from these attacks would come during the reign of Hezekiah, "the future king of Judah." In addition to being a "mighty hero," Hezekiah would be "a perpetual, constant father," the "devoted benefactor of his people," and a "Prince of Peace" under whose rule Judah would enjoy a time of "tranquillity." Adler says this latter designation is especially unsuited to Jesus, who said he "came not to send peace, but a sword." Applying it to Hezekiah, however, would be consistent not only with the interpretations set forth by "our most ancient and valued commentators," but also with what he believes is the "unanimous" position of Christian grammarians like Wilhelm Gesenius (17861842)..$^{56}$

Adler holds that inaccurate readings of Isaiah 52 and 53 began with the Gospel writers themselves, who crafted their work "in such manner as to tally with the prophecies" presented there. To use "a homely but expressive simile," he says, "the foot was cut so as to fit the shoe." A proper interpretation reads these texts not in isolation, or as part of a preconceived agenda, but rather as part of Isaiah's discussion of Israel's captivity beginning in chapter forty. These chapters are indeed prophetic, but they speak of a nation, not an individual. Adler understands Israel to be the "servant of the Lord"; the people's "sufferings and degradation were necessary for the accomplishment of his mission," but their "glorious exaltation in the latter days" will draw "the nations of the world...to put their faith in the One and Only God." 57

Adler begins his discussion of Daniel in Sermon VII and devotes all of Sermon VIII to the eschatological vision at the end of chapter 9. He says that it has received more attention, by both Jewish and Christian commentators, than virtually any other passage. His task, then, is to sort through the "mass of interpretation which these few verses have called forth" and "treat the subject in as simple manner as possible." Here too he seeks the most accurate meaning of key words and phrases, placing them in their proper historical context. The terms "Most Holy" in verse 24 and "prince" in verse 25 , for example, always refer to "part of the Temple" and a person "invested with temporal authority"; they, therefore, cannot "apply to the Nazarene." 58

\footnotetext{
${ }^{55}$ Adler, Course of Sermons, 23, 30.

${ }^{56}$ Adler, Course of Sermons, 21, 24, 25; Executive Committee of the Editorial Board and Joseph Jacobs, "Gesenius, Heinrich Friedrich Wilhelm," http://www.jewishencyclopedia.com/articles/6636gesenius-heinrich-friedrich-wilhelm.

${ }^{57}$ Adler, Course of Sermons, 27, 31.

${ }^{58}$ Adler, Course of Sermons, 104, 105, 117.
} 
Adler argues that the Christian views of Daniel's entire timeline-70 weeks, divided into periods of 7,62, and 1, with the final week itself broken into two parts - are similarly untenable. The "various hypotheses" they have constructed are, he says, grounded in historical inaccuracies and misunderstandings of Hebrew grammar, and there is no satisfactory way "to make chronology tally with their explanation of the prophecy." All the difficulties can be resolved, however, by reading the passage through a Jewish lens. Adler proposes that it "most probably...refers to the persecutions and oppressions which Israel was destined to endure at the hands of the cruel and fanatic Antiochus Epiphanes." Its purpose, then, was to "encourage the Jews to remain faithful to their God" and to assure them that there would eventually come a time when "their sufferings would be at an end, their iniquity pardoned, the piety and righteousness of old re-established, and the holy of holies again anointed." This time did in fact come, but not with the birth and death of Jesus of Nazareth. Rather, the prophecy was fulfilled "in the renewed dedication of the temple by Judas Maccabeus, and the reestablishment shortly afterwards of the independence of Israel." Adler concedes that, "owing to our uncertain comprehension of Biblical Chronology, absolute numerical precision seems almost unattainable," but he remains convinced that this interpretation is much more accurate than any Christian view. ${ }^{59}$

It is important to note these sermons are not direct responses to sermons preached on behalf of the Society. Adler seldom discusses precisely the same passages addressed in those sermons, he makes no allusions to the Society after the first few pages of the volume, and while he often mentions "Christian theologians" and "Christian expositors," he does not refer to any contemporary figures by name. The closest we have to an actual point-counterpoint is a "demonstration sermon" preached by an S. Newton in the Jews' Chapel on August 30, $1812^{60}$ and Sermon VI in Adler's volume, delivered on June 6, 1868. Adler does not explicitly refer to Newton, but fruitful comparisons can nonetheless be made, as both take Psalm 110 as their primary scripture texts, and both were preached to Jews.

Early in his sermon, Newton suggests that Jews and Gentiles would agree that "a reference to the Psalms, is a reference to decisive authority, and that whatever was really written in the $110^{\text {th }}$ Psalm is true and ought to be believed." ${ }^{\text {,61 }}$ I suspect Adler would concur, and that may very well be their only point of common ground, for the two preachers expressed very different views on what was "really written" there.

The disagreements begin with the very title of the psalm. Newton calls it "a Psalm of David, a title which, for the most part, remains undisputed." ${ }^{22}$ Adler, however, disputes it, asserting that it "most probably... does not signify a Psalm of

\footnotetext{
${ }^{59}$ Adler, Course of Sermons, 110, 14, 20.

${ }^{60}$ S. Newton, "The Eleventh Demonstration Sermon...," The Jewish Repository, or Monthly Communications Respecting the Jews, and the Proceedings of the London Society 1 (1813): 15-18, 52-57, 9094.

${ }^{61}$ Newton, "Eleventh," 16.

${ }^{62}$ Newton, "Eleventh," 16.
} 
David, but for (concerning) David." ${ }^{, 63}$ The italicized words are short but crucial, as the reading adopted here will drive the interpretation of the entire psalm. If David is taken to be the author, then the psalm can be viewed as messianic; if he is the object, then it is concerned with his own times.

This is precisely the difference we see in these two sermons. To Newton, for example, both uses of the word "Lord" in verse 1- "The Lord said unto my Lord..."- - signify the divine, the former referring to Jehovah, the latter to the "Lord of David." ${ }^{64}$ Adler, on the other hand, takes the second instance as "my master," a word that "simply denotes superiority." $"$ "Newton goes on to argue that the other "truths contained in the text...are applicable only to Jesus Christ," ${ }^{66}$ a claim that Adler regards as easily falsifiable. Jesus, he says, could not be "a priest forever after the order of Melchizedek" because he never performed the priestly duties of "perform[ing] divine service and offer[ing] sacrifices," nor could he be the warrior mentioned in the final verses, because "no record...exists of battles which the Nazarene fought." In short, what Newton frequently refers to as the "plain" reading of the text is not self-evident to Adler at all. The traditional Christian exegesis, he says, is rife with "absurdities and errors"; only focusing on David rather than on Jesus will result in "a satisfactory explanation of the Psalm" and "sweep away the dogmatic cobwebs with which [it] has been covered in the process of ages." 67

\section{Responses to Adler}

A Course of Sermons received several reviews, published in both Jewish and Christian periodicals; according to The Jewish Chronicle, the volume "achieved the remarkable success of attracting to itself a whole page in the British Museum Catalogue wherein to describe the various replies it evoked." ${ }^{, 68}$ One such notice could be described as a nonpartisan move: The Jewish Chronicle for December 2, 1870 printed an excerpt from a review in a newspaper called The North Wilts Herald, which was likely published in Wiltshire, a county bordering Berkshire, Oxfordshire, and other regions of southwest England. The reviewer was evidently a Christian, writing that "we do not, and cannot, take our stand side by side with Dr. Adler-for to do so would be apostacy from our Lord." He nevertheless commended Adler for his "scholarship and general ability," and recommendedalbeit "Upon the principle of learning from an enemy"- the "perusal of this carefully prepared and measured statement of differences between Jews and Christians, as set forth by a pious and enlightened authority in the synagogue." 69

\footnotetext{
${ }^{63}$ Adler, Course of Sermons, 83.

${ }^{64}$ Newton, "Eleventh," 17.

${ }^{65}$ Adler, Course of Sermons, 80.

${ }^{66}$ Newton, "Eleventh," 16.

${ }^{67}$ Adler, Course of Sermons, 79, 81, 82, 89.

68 "The New Chief Rabbi," The Jewish Chronicle (June 5, 1891): 11.

69 “The Rev. Dr. H. Adler's Sermons,” The Jewish Chronicle (December 2, 1870): 7.
} 
Most of the other reviews, however, fell along largely sectarian lines. An 1869 piece by one of The Jewish Chronicle's own reviewers, for example, commended Adler for his "courage and good sense," the "sharp conciseness in his style," and his ability to combine "the fervor of a preacher with cool acumen worthy of a lawyer." The sermons address an issue which "seems hitherto not to have received, in this country at least, the full consideration which is its due," leading the reviewer to praise them as "a valuable addition to Anglo-Jewish literature.,"70 Positive comments appeared in the Chronicle as late as 1921, over fifty years after the publication of the sermons. An article entitled "The New Testament in Synagogue Classes" includes a letter in which J. H. Hertz, who succeeded Adler as Chief Rabbi, lauded his predecessor for publishing an "altogether admirable" and even "priceless" book. ${ }^{71}$

One review from a Christian perspective came from the Society itself, in the form of a "reply" published in the Jewish Intelligence. The reply is divided into two parts, each one addressing what the reviewer, one Rev. W. Ayerst, saw as one of Adler's major errors. In the first, published on February 1, 1870, Ayerst focuses on the Trinity, accusing Adler of ignoring the many passages in the Old Testament "which shew so clearly that the Jews of old believed in a "plurality in the unity of the Godhead'." The following month, he wrote on the atonement, which Adler had called a "repugnant" and "monstrous" idea. He asserts that it is rather "in exact accordance with the law of Moses," and that "ancient orthodox doctrine" attests to the coming of "a suffering as well as a glorious Messiah." Ayerst's entire rebuttal, in fact, rests not on Adler's disagreements with Christian teaching, but on what he sees as his rejection of his own faith. As he puts it at the very beginning of his reply, "If Dr. Adler is right, the ancient fathers of that Church [i.e. Judaism] erred grievously; if they were right, Dr. Adler is greatly in the wrong." 72

People not associated with the Society reviewed Adler's book as well. One appraisal appeared on June 1, 1869 in The Scattered Nation, a short-lived periodical founded and edited by Carl Schwartz, a Jewish convert to Christianity. The reviewer described the sermons as "well-written but very superficial" works, that failed to present "one single new objection." They might, he suggested, even work against Adler's purpose by spurring "a spirit of inquiry among the Jews," which would do "the cause of Christ a very great service.", "3

An even less charitable assessment appeared the following year in the British Quarterly Review, a well-established publication addressed to evangelical and nonconformist readers. The writer acknowledged that it was "right that he should confirm and establish his flock in their ancient faith" but criticized his methods of doing so, accusing him of unfairly framing "the arguments of his opponents with

\footnotetext{
${ }^{70}$ Review of A Course of Sermons, by H. Adler, The Jewish Chronicle (July 2, 1869): 9.

71 "New Testament in Synagogue Classes. The Chief Rabbi's Explanation," The Jewish Chronicle (November 25, 1921): 15.

${ }^{72}$ W. Ayerst, "The Christianity of the Old Testament. Being a Reply to 'Twelve Sermons' by Dr. Hermann Adler," Jewish Intelligence... 36 (1870): 31, 33, 49, 56.

${ }^{73}$ Review of A Course of Sermons, by Hermann Adler, Ph.D., The Scattered Nation 4 (1869): 151.
} 
a direct view to the convenience of knocking them down again." Adler's arguments, the reviewer asserted, were so "feeble" and unoriginal that it would be a great surprise "if this work should seriously disturb any Christian, or contribute much to the establishment of his own congregation in the faith of their fathers."

The sermons elicited several pamphlet- and book-length responses as well. In 1879, ten years after Adler published his collection, the Scottish minister Paton James Gloag ${ }^{75}$ used the pulpit of Blythswood Church in Glasgow to deliver the Baird Lectures, an annual event endowed in 1873 for "the illustration and defence of the vital truths" of Christianity and "for the exposure and refutation of all error and unbelief." "In a Supplement included with the published texts, Gloag called Adler's work "a valuable series of discourses" by a "distinguished Jewish minister" and noted that they "will be frequently adverted to in these lectures." "Frequent," however, may be an overstatement, as he mentions Adler fewer than twenty times in 366 pages, usually without detailed discussion, and mostly only in this supplement, not in the lectures themselves. The volume then, can hardly qualify as a close examination of Adler's work.

Other publications, however, focused exclusively on Adler. The anonymous 1870 On Some Points of Dispute Between Jews and Christians takes up each of his sermons in turn, giving detailed attention to the first two but petering out towards the end. Like Ayerst, the reviewer asserts that "the plural meaning of Elohim... was acknowledged by the Jewish Fathers" and that the "principle of vicariousness can be found in the fifty-third chapter of Isaiah" and states that any Jew who denies the messianic significance of Isaiah 7:14-"The virgin will conceive and give birth to a son"- "rejects the highest meaning of his own Scriptures." He goes beyond Ayerst, however, to appeal to passages from the Christian scriptures as well. He notes, for example, that Matthew 1:22-23 speaks of Jesus' birth as the fulfillment of Isaiah's prophecy, attempts to show that "an argument, with reference to the Messiahship of Jesus" can be "constructed from His own statements," and maintains that the whole of the New Testament affirms vicariousness. "From the exclamation of John the Baptist," he writes, "to the last chapter of the Revelation,...the sufferer is the Divine Son, and the atonement is

\footnotetext{
${ }^{74}$ Review of A Course of Sermons Preached in Bayswater Synagogueand An Examination of Twelve Sermons by Dr. Adler, British Quarterly Review 52 (1870): 257-58. The reviewers' assertions that Adler was more derivative than innovative may not be entirely without merit. Just as the Society preachers offered fairly conventional interpretations and applications of their scripture texts, Adler's refutation of their arguments is grounded in a long history of Jewish thought. Some of the statements he makes in A Course of Sermons, for example, are virtually identical to those found in works such as the Nizzahon Vetus, "a virtual anthology of Ashkenazic polemic in the twelfth and and thirteenth centuries" (David Berger, The Jewish-Christian Debate in the High Middle Ages [Philadelphia: The Jewish Publication Society of America, 1979], 17). For a discussion of the texts to which Adler refers, see Berger's translation and commentary on pp. 102-05, 114-16, 132, 160-65, 277-78, 282-83, 290, 307-09.

${ }^{75}$ See James Lachlan MacLeod, "Gloag, Paton James (1823-1906, Church of Scotland Minister and Theologian." ODNB (September 23, 2004), on line, retrieved October 20, 2018.

${ }^{76}$ James Baird, "The Baird Trust": Deed of Trust (Glasgow: The University Press, 1873), 11.

${ }^{77}$ Paton J. Gloag, The Messianic Prophecies (Edinburgh: T. \& T. Clark, 1879), 38.
} 
made by God Himself." 78 For both reviewers, pointing out the flaws in Adler's sermons is not an end in itself, but a means to a spiritual goal: Ayerst hopes that his readers, like the Psalmist, will ask God to help them see "wondrous things out of [his] Law"; the author of Some Points concludes with an appeal to "investigate [Christianity's] claims honestly, earnestly and patiently" and to "ponder the question, whether One who lived, and laboured, and taught, and died as Jesus did, could have done so to propagate error and falsehood." 79

Two other pamphlets, also published in 1870, respond to Adler's explicit invitation to engage those who disagree with him, In his fourth sermon, he discusses Deuteronomy 18:15, "The Lord thy God will raise up unto thee a prophet from the midst of thee, of thy brethren, like unto me; unto him shall ye hearken." He rejects the notion set forth by Matthew Henry, author of the wellknown Exposition of the Old and New Testaments (1708-1710), that the verse is a messianic prophecy and "boldly [challenges] every professor of the Christian faith to tell [him] where it is stated that the prophet, like unto Moses, was to declare a new revelation." $" 80$

This statement is quoted in the anonymous Analytical Review of Twelve Sermons, a seventy-three page pamphlet which, like Some Points, examines each of Adler's discourses in turn. The title page makes distaste for Adler evident from the start, stating that the sermons are "compounded of rabbinical orthodoxy and rationalistic aberration." The attacks continue throughout the text itself, as the author accuses Adler of "perversity," insincerity, taking passages out of context, engaging in "groveling, tortuous misapplication" of the scriptures, and "loathingly strain[ing] at a 'gnat" while "swallow[ing] with perfect ease a "camel," the same condemnation Jesus issues of the scribes and Pharisees in Matthew 23. ${ }^{81}$ This combative tone shows the same "animus" that is attributed to Adler on the title page; it also makes the word "analytical" somewhat ironic, as the author's prevailing rhetorical strategy seems to be employing pathos rather than logos, making his case through inflammatory language rather than reasoned discourse.

Adler's challenge is also taken up in The Wonderful Word "Jah," a reference to a "remarkable and mysterious name" for God that, according to its author Edward Poulson, ${ }^{82}$ appears only "forty-nine times in the Bible, twice in Exodus, forty-three times in the Psalms, and four times in Isaiah." Poulson attempts to re-

\footnotetext{
${ }^{78}$ On Some Points in Dispute between Jews and Christians... (London: Longmans, Green, Reader, and Dyer, 1870), 1, 20, 23, 44, 46.

${ }^{79}$ Ayerst, "The Christianity of the Old Testament," 57; On Some Points in Dispute, 78.

${ }^{80}$ Adler, Course of Sermons, 50, 54.

${ }^{81}$ Analytical Review of Twelve Sermons... (London: William Macintosh, 1870), 15-16, 32, 48, 69.

${ }^{82}$ Thanks to Susan Hoyle, Malcolm Shifrin, and Timothy Stunt for responding to inquiries about Poulson submitted to the VICTORIA email list. He was apparently associated with the "Strict," or "Strict and Particular," Baptists, an evangelical group known for "restricting" the observance of communion to those who had been "baptised by immersion as believers," and for teaching that salvation was available only to a "particular," preordained group of people rather than the entire world ("Who are the Strict Baptists?," http://www.sbhs.org.uk/membership/strictbapt/). Several other works, such as The Crimes of Atheism... (1886), similarly illustrate his penchant for engaging in religious discussion and debate.
} 
fute Adler by asserting that Moses did in fact "declare a new revelation," one that disclosed the triune nature of God. His evidence includes the plural nature of the world "Elohim," the idea that the phrase "the Angel of the Lord" refers to God in bodily form, and the view that the three men who appeared to Abraham in Genesis 18 "personified the Triune Jehovah." He then extends his argument beyond the Pentateuch, asserting that prophecies of the messiah and allusions to the Trinity can also be found in such books as 1 Kings, Psalms, Isaiah, Daniel, and Hosea. ${ }^{83}$

A Course of Sermons was clearly the inspiration for this fifty-page pamphlet, but Poulson can credibly claim, as he does on the same page where he accepts Adler's challenge, that his "motive in writing is not to address my remarks to any individual personally, but strictly to principles for the vindication of the truth of Scripture." His primary principle seems to be that interpretations should be derived from "the plain literal testimony of the Law and the Prophets." Without such testimony, especially as it attests to "the Most Holy Trinity of three distinct...persons in one undivided Jehovah," the scriptures would, in Poulson's view, be reduced to "a mass of confused contradiction and heathen mythology." 84 While allusions to Adler are present throughout the text, literal exegesis is in fact the dominant concern. Poulson's position, like Adler's, is certainly open to debate, but it is developed rationally and in some detail, with none of the vitriol and ad hominem attacks that characterize the Analytical Review.

Many of these responses received reviews of their own. The author of a "Literary Notice" in the Methodist London Quarterly and Holborn Review called Some Points "an admirable answer to some of the salient points of attack" raised in Adler's sermons. ${ }^{85}$ J. C. S. Kroenig, identified in the byline as "Curate of Holy Trinity, Hull," praised the Analytical Review in an 1872 article in The Hebrew Christian Witness and Prophetic News. He stated that the book "effectually disposed of" Adler's sermons and recommended it "to all interested in the question. ${ }^{" 86}$ Several British periodicals and an American journal called The Old Testament Student reviewed Gloag's book, ${ }^{87}$ but the only one to treat it as a response to Adler was a half-page notice in the July 15, 1879 issue of The Jewish Chronicle. The review is rather charitable, recognizing Gloag as "an eminent and

\footnotetext{
${ }^{83}$ Edward Poulson, The Wonderful Word "Jah." ...(London: Houlston and Sons, 1870), 6-8, 12-14, 20-22, 44-45.

${ }^{84}$ Poulson, The Wonderful Word "Jah," 6.

${ }^{85}$ Review of On Some Points in Dispute..., London Quarterly and Holborn Review 33 (1870): 504.

${ }^{86}$ J. C. S. Kroenig, "What Is Christianity? Introduction," The Hebrew Christian Witness and Prophetic News 4, New Series (1872): 50.

${ }^{87}$ Review of The Messianic Prophecies, by Paton James Gloag and The Hebrew Utopia, by Walter F. Adeney, British Quarterly Review 70, no. 140 (1879): 541-43; "The Baird Lecture for 1879, and "the Hebrew Utopia,", The Wesleyan-Methodist Magazine 4, Sixth Series (1880): 134-39; Review of The Messianic Prophecies. Being the Baird Lecture for 1879, by P.J. Gloag, The United Presbyterian Magazine 23, New Series (1879): 465-66; “Messianic Prophecy," The Old Testament Student 3, no. 6 (1884): 217-18.
} 
scholarly Scotch divine" and commending "the fair and dignified spirit...in which the volume is couched." ${ }^{\prime 88}$

According to this article, even Adler himself had joined the ranks of the respondents, having "commenced a series of discourses at his Synagogue, in which he defends the interpretations in his printed volume of sermons and gives the Jewish explanation of the several other texts adduced by Dr. Gloag in support of Christian evidence and Christian doctrine. ${ }^{" 89}$ A discussion of these talks would have been an excellent way of bringing the conversation full circle, but it appears that they have not survived.

\section{Conclusion}

In April 1927, someone identified only as A. Lyons mentioned Adler in a letter to the editor of The Jewish Chronicle. It appears that Adler had tried to distance himself from A Course of Sermons, asking Lyons not to remind him of his "youthful indiscretion." When and why Adler would have made such a statement is uncertain. Lyons, however, clearly disagreed with this assessment, writing that it is "an admirable little work, now very scarce, and I am glad to possess a copy.",90

Adler's book is no longer scarce, as it is now available to all via the HathiTrust Digital Library and the Internet Archive. I would argue, moreover, that it was neither "youthful" nor "indiscreet." Adler, was, after all, nearly thirty years old when he delivered the sermons. By that time, he had earned a Ph.D.; been the principal of Jews' College, a rabbinical seminary in London; and served as the minister of Bayswater Synagogue for five years. He had also gained a positive reputation in the Jewish community. His "considerable talent and ability" had been recognized as early as 1859 , the year in which he took "his degrees at the London University with great honour." ${ }^{.91}$ A few years later, in 1863, The Jewish Chronicle and Hebrew Observer noted that the Bombay Gazette had hailed him as a man of "real and profound learning"; ${ }^{22}$ several other articles and letters to the editor published before he delivered A Course of Sermons took note of the earnestness and eloquence of his preaching. ${ }^{93}$

\footnotetext{
88 “The Baird Lecture for 1879," The Jewish Chronicle (July 25, 1879): 13.

89 "The Baird Lecture for 1879," 13.

${ }^{90}$ A. Lyons, "Biblical 'Christological' Passages," The Jewish Chronicle (April 1, 1927): 48.

91 "Consecration of the New Synagogue at Swansea," The Jewish Chronicle and Hebrew Observer (October 7, 1859): 5 .

92 "Refutation of Colenso's Arguments," The Jewish Chronicle and Hebrew Observer (March 27, 1863): 6 .

93 "Abstract of a Sermon (Delivered by Mr. Hermann Adler, on the First Day of New Year, at the New Synagogue)," The Jewish Chronicle and Hebrew Observer (September 28, 1860): 5; "Sermon by Dr. Hermann Adler," The Jewish Chronicle and Hebrew Observer (October 3, 1862): 4; "Birmingham.-Special Service," The Jewish Chronicle and Hebrew Observer (November 7, 1862): 5; "The Fire at Monastir and the Bayswater Synagogue," The Jewish Chronicle and Hebrew Observer (October 2, 1863): 6; "Sermon at the Free School," The Jewish Chronicle and Hebrew Observer (April 13, 1866): 5; "Jews' College," The Jewish Chronicle and Hebrew Observer (December 13, 1867): 5 .
} 
I also do not see $A$ Course of Sermons as untoward or inappropriate in any way. He published the collection only after being asked to do so by "a great number of my own Congregation, as well as by other members of the Jewish Community." ${ }^{94}$ As he notes in the Preface, the sermons had been preached to defend the faith from outside attacks, especially those waged by the Society; they are not offensive, either in the sense of "going on the offense" to win converts to Judaism, or in the sense of "likely to offend" his hearers and readers. He does call out and seek to correct what he believes to be erroneous teaching by his Christian counterparts, but he does so without the animosity and strident tone we see in some of his critics.

The fact that he had critics shows that Adler had positioned himself within an ongoing conversation taking place in the pulpit and the press. This conversation continues to be significant today; the intersection of Jewish-Christian relations and sermon studies - not just in Victorian England, but in a range of locations and time periods - is a topic that can be more fully and fruitfully explored.

${ }^{94}$ Adler, Course of Sermons, iii. 